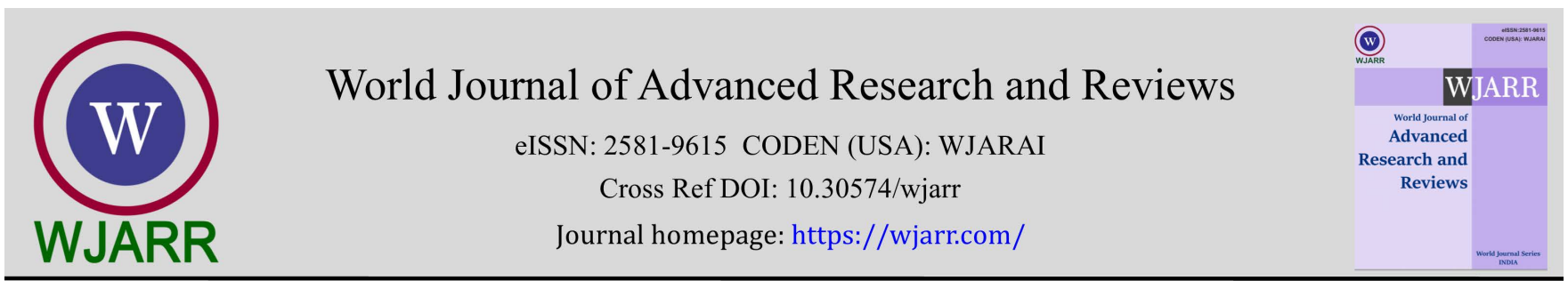

(RESEARCH ARTICLE)

Check for updates

\title{
Effect of moringa leaf meal and season on blood and hormonal profile of the pearl guinea fowl (Numida meleagris)
}

\author{
Poku Jnr PA *, Kagya-Agyemang JK, Kwenin WKJ, Bonsu FRK and Kyere CG \\ Department of Animal Science Education, Faculty of Agriculture Education, University of Education, Winneba, Post Office \\ Box 40, Mampong-Ashanti, Ghana.
}

World Journal of Advanced Research and Reviews, 2021, 11(03), 078-092

Publication history: Received on 16 July 2021; revised on 05 September 2021; accepted on 07 September 2021

Article DOI: https://doi.org/10.30574/wjarr.2021.11.3.0388

\begin{abstract}
This study was undertaken to determine the effect of moringa leaf meal and season on blood and hormonal profile of the Pearl Guinea fowl (Numida meleagris) in the Middle belt of Ghana. Thirty-two (32) males and one hundred and twenty-eight (128) female Pearl Guinea fowls aged one-day-old were used for the study. A 3 x 4 factorial experimental design was used for the experiment. Data collected were analyzed using General Linear Model (GLM) procedure of Statistical Analysis System (SAS for Windows, version 7) and means were separated by the probability of difference (PDIFF) procedure of SAS (2008). Mean cell volume was highest (175.39 fl) among Guinea fowls fed with diet containing $12 \%$ moringa leaf meal level. Guinea fowls fed with diet containing $15 \%$ moringa leaf meal had the highest (3.44 $\left.x 10^{12} / L\right)$ red blood cells production. Eosinophil level was highest $\left(3.95 \times 10^{12} / L\right)$ among Guinea fowls fed with diet containing $9 \%$ moringa leaf meal. Birds fed with the moringa diets recorded the highest $(\mathrm{P}=0.022) \mathrm{WBC}$ values as compared to the control diet. Triglycerides, high density lipoprotein and low-density lipoprotein levels increased $(\mathrm{P}<0.05)$ with increasing levels of dietary moringa leaf meal in the diet. The highest $(\mathrm{P}=0.0025)$ level of progesterone was observed among birds fed with diet containing 12 and $15 \%$ moringa leaf meal inclusion levels. The level of sodium was highest (166.69 nmol/l) among Guinea fowls fed with diet containing $12 \%$ moringa leaf meal. The major and minor rainy seasons recorded the highest $(\mathrm{P}<0.05)$ mean cell hemoglobin, red blood cells, albumin and oestrogen levels. Platelets, follicle stimulating hormone, luteinizing hormone, prolactin and chlorine levels were highest $(\mathrm{P}<0.05)$ in the dry season while basophil level was highest in the major rainy season. Cholesterol, triglycerides, high density lipoprotein, low density lipoprotein and potassium levels were highest $(\mathrm{P}<0.05)$ in the major rainy season. This study concludes that feeding Guinea fowls with moringa leaf meal had positive effect on some haematological, biochemical and hormonal parameters.
\end{abstract}

Keywords: Moringa leaf meal; Season; Erythrocytes; Platelets; Leukocytes; Hormonal; Metabolites

\section{Introduction}

In many parts of the world, Guinea fowls are raised mainly for their gamey flesh and eggs. Guinea fowl has a taste similar to other game birds and has many nutritional qualities that make it a worthwhile addition to the diet. The meat of a young Guinea fowl is tender and of especially fine flavour, resembling that of wild game [1]. Guinea fowl meat has a higher protein content of approximately $28 \%$ compared to $20 \%$ for domestic fowl [2]. Guinea fowls play a significant role in the lives of people in Northern Ghana, ranging from socio-cultural to economic and religious purposes [3]. With the realization for increased animal source of protein in the diets of the average Ghanaian, it is becoming increasingly important to adopt efficient methods to improve animals' performance. This will involve changes in management practices and provision of adequate and appropriate health schemes [4].

\section{${ }^{*}$ Corresponding author: Poku Jnr AP}

Department of Animal Science Education, Faculty of Agriculture Education, University of Education, Winneba, Post Office Box 40, Mampong-Ashanti, Ghana.

Copyright (@ 2021 Author(s) retain the copyright of this article. This article is published under the terms of the Creative Commons Attribution Liscense 4.0. 
Guinea fowl production in Ghana is constrained by the levels of hormonal production, low body weight at first maturity, out of season breeding and seasonal changes. The number of eggs laid depends on hormonal production, nutrients levels in the diet, breeding stock and health status of the bird [5]. Seasonal changes can lead to Guinea fowl hens not laying at certain times of the year. Short-day length affects egg laying because it affects hormonal production and hence reproduction [6]. Poor nutrition can lead to inadequate protein and other nutrients in the diet which can affect fertility, hatchability, growth performance and sperm production.

Recently, there has been interest in the utilization of moringa (Moringa oleifera) commonly called horseradish tree or drumstick tree, as a protein source for livestock [7, 8]. Moringa leaves have quality attributes that make it a potential replacement for soyabean meal or fish meal in non-ruminant diets. Moringa oleifera is in the group of high-yielding nutritious browse plants with every part having food value [8]. The leaves, flowers and pods are used as good sources of vitamins A, B and C, riboflavin, nicotinic acid, folic acid, pyridoxine, ascorbic acid, beta-carotene, calcium, iron, and alpha-tocopherol [9].

The use of moringa in livestock ration is limited by the presence of anti-nutritional factors [7]. However, the presence of these anti-physiological agents in moringa products is removed via air drying, soaking or boiling in water [8]. AbouSekken [9] reported that growth-promoting effect in chicken may be due to its direct nutritional and immunestimulating actions of its phytochemicals. The positive and negative impact of phytochemicals properties in moringa leaf meal have been reported by Ogbe [8] and AbouSekken [9]. According to the work done by Ogbe [8], phytochemicals in moringa leaf meal have significant effect on the blood constituent of broiler chicken. A phytochemical analysis in moringa leaf meal conducted by Ogbe [8] revealed that chlorogenic acid and its isomers are esters of quinic and caffeic acids that have abilities to inhibit oxidation and also promote various pharmacological activities such as antiobesity, reduction of plasma and liver lipids, and inhibition of acute lung injury.

The present investigation was undertaken to study the effect of moringa leaf meal and season on blood and hormonal profile of the Pearl Guinea fowl (Numida meleagris) in Ghana.

\section{Material and methods}

\subsection{Study location and duration}

The study was conducted at the Poultry Unit of the Department of Animal Science Education, University of Education, Winneba, Mampong-Ashanti, Ghana. Mampong-Ashanti lies in the transitional zone between the Guinea savanna zone of the north and the tropical rain forest of the south of Ghana. The climatic, vegetation and demographic characteristics of Mampong-Ashanti have been described by [10]. Mampong-Ashanti lies between latitude 070 04' degree north and longitude $01^{\circ} 24^{\prime}$ degrees west with an altitude of $457 \mathrm{~m}$ above sea level. Maximum and minimum annual temperatures recorded during the study period were $30.6{ }^{\circ} \mathrm{C}$ and $21.2{ }^{\circ} \mathrm{C}$, respectively $[11,12]$. Rainfall pattern in the district is bimodal, occurring from April to July (major rainy season) and again August to November (minor rainy season), with about $1224 \mathrm{~mm}$ per annum. The dry season occurs from December to March [13]. The vegetation is transitional savanna woodland, which guarantees proper poultry keeping on free range basis.

\subsection{Experimental birds, treatment and design}

One hundred and sixty (160) birds were used for the study. This comprised thirty-two (32) males and one hundred and twenty-eight (128) females. A 3 x 4 factorial experimental design was used. The factors considered included; Factor I Season at 3 levels (Dry season -December-March, Major rainy season - April-July and Minor rainy season -AugustNovember) and Factor II: Different levels of Moringa leaf meal (MOLM) (moringa leaf meal at four levels: $0 \%$ MOLM, 9 $\%$ MOLM, $12 \%$ MOLM and $15 \%$ MOLM). All treatment combination (Season and different levels of moringa leaf meal combination: 0 \% MOLM: Dry season, Major rainy season and Minor rainy season, 9 \% MOLM: Dry season, Major rainy season and Minor rainy season, 12 \% MOLM: Dry season, Major rainy season and Minor rainy season, 15 \% MOLM: Dry season, Major rainy season and Minor rainy season) were used. Each treatment was replicated four times and had ten birds per replicate. The birds in each replicate were housed in one pen. At four (4) months old, a male was paired with four Guinea hens based on National Research Council 2006 recommendation for Guinea fowl [14].

\subsection{Housing, Feeding and Medication}

A total of sixteen (16) experimental pens were used for rearing the birds, each measuring $1.4 \mathrm{~m} \times 1.34 \mathrm{~m}$ and housed ten (10) birds. The floor was concreted, and wood shavings were used as litter for the birds. Removable wooden feeding troughs measuring $0.8 \mathrm{~m} \times 0.04 \mathrm{~m} \times 0.03 \mathrm{~m}$ were used for feeding the growers. 
Table 1 Ingredient and composition (\%) of Starter diet

\begin{tabular}{|l|c|c|c|c|}
\hline Attributes & 0\% MOLM & 9\% MOLM & 12\% MOLM & 15\% MOLM \\
\hline Moringa & 0.00 & 9.00 & 12.0 & 15.0 \\
\hline Maize & 57.5 & 54.0 & 52.5 & 52.0 \\
\hline Wheat bran & 11.0 & 8.50 & 8.50 & 6.00 \\
\hline Soya bean meal & 8.50 & 8.00 & 7.00 & 7.00 \\
\hline Tuna fish meal & 8.00 & 6.50 & 6.00 & 6.00 \\
\hline Anchovy fish meal & 12.0 & 11.0 & 11.0 & 11.0 \\
\hline Oyster shell & 1.50 & 1.50 & 1.50 & 1.50 \\
\hline Dicalcium phosphate & 0.50 & 0.50 & 0.50 & 0.50 \\
\hline Vitamin premix & 0.50 & 0.50 & 0.50 & 0.50 \\
\hline
\end{tabular}

Table 2 Ingredient and composition (\%) of Grower diet

\begin{tabular}{|l|c|c|c|c|}
\hline Attributes & 0\% MOLM & 9\% MOLM & 12\% MOLM & 15\% MOLM \\
\hline Moringa & 0.00 & 9.00 & 12.0 & 15.0 \\
\hline Maize & 63.0 & 60.5 & 56.0 & 58.0 \\
\hline Wheat bran & 22.0 & 18.5 & 16.0 & 17.0 \\
\hline Soya bean meal & 3.00 & 2.00 & 3.00 & 2.00 \\
\hline Tuna fish meal & 4.00 & 3.00 & 4.00 & 2.00 \\
\hline Anchovy fish meal & 5.00 & 4.00 & 6.00 & 3.00 \\
\hline Oyster shell & 1.50 & 1.50 & 1.50 & 1.50 \\
\hline Dicalcium phosphate & 0.50 & 0.50 & 0.50 & 0.50 \\
\hline Vitamin premix & 0.50 & 0.50 & 0.50 & 0.50 \\
\hline
\end{tabular}

Table 3 Ingredient and composition (\%) of Breeder diet

\begin{tabular}{|l|c|c|c|c|}
\hline \multicolumn{1}{|c|}{ Attributes } & 0\% MOLM & 9\% MOLM & 12\% MOLM & 15\% MOLM \\
\hline Moringa & 0.00 & 9.00 & 12.0 & 15.0 \\
\hline Maize & 55.0 & 50.0 & 50.0 & 50.0 \\
\hline Wheat bran & 19.5 & 18.5 & 16.5 & 14.5 \\
\hline Soya bean meal & 4.00 & 3.00 & 2.50 & 2.00 \\
\hline Tuna fish meal & 4.50 & 4.50 & 4.00 & 3.00 \\
\hline Anchovy fish meal & 8.00 & 6.00 & 6.00 & 6.50 \\
\hline Oyster shell & 7.50 & 7.50 & 7.50 & 7.50 \\
\hline Dicalcium phosphate & 0.50 & 0.50 & 0.50 & 0.50 \\
\hline Vitamin premix & 0.50 & 0.50 & 0.50 & 0.50 \\
\hline
\end{tabular}


A 4.5-litre watering trough was used for supplying water ad libitum for the growers in each pen. The experimental diets (Table 1, 2 and 3) were supplied to the birds ad libitum throughout the experimental period, vaccination and other routine poultry practices were also carried out. The weather records for the 2017 and 2018 are shown in Tables 4 and 5 .

Table 4 Average Weather Records for the Experimental Location in the first year

\begin{tabular}{|l|c|c|c|}
\hline \multicolumn{1}{|c|}{ Variables } & $\begin{array}{c}\text { Dryseason } \\
\text { (December-March) }\end{array}$ & $\begin{array}{c}\text { Major Rainy Season } \\
\text { (April-July) }\end{array}$ & $\begin{array}{c}\text { Minor Rainy Season } \\
\text { (August-November) }\end{array}$ \\
\hline Temperature $\left({ }^{\circ} \mathrm{C}\right)$ & 32.0 & 30.25 & 27.0 \\
\hline Rainfall $(\mathrm{mm})$ & 27.28 & 130.0 & 125.05 \\
\hline Humidity $(\%)$ & 65.5 & 81.25 & 84.5 \\
\hline Cloud cover (\%) & 37.50 & 60.00 & 65.25 \\
\hline Sun Hours (hr.) & 103.10 & 89.30 & 62.45 \\
\hline
\end{tabular}

Table 5 Weather Records for the Experimental Location in the second year

\begin{tabular}{|l|c|c|c|}
\hline Variables & $\begin{array}{l}\text { Dry season } \\
\text { (December-March) }\end{array}$ & $\begin{array}{l}\text { Major Rainy Season } \\
\text { (April-July) }\end{array}$ & $\begin{array}{l}\text { Minor Rainy Season } \\
\text { (August-November) }\end{array}$ \\
\hline Temperature $\left({ }^{\circ} \mathrm{C}\right)$ & 33.0 & 29.11 & 26.30 \\
\hline Rainfall $(\mathrm{mm})$ & 28.41 & 123.12 & 117.02 \\
\hline Humidity $(\%)$ & 68.9 & 82.07 & 80.11 \\
\hline Cloud cover (\%) & 38.80 & 65.21 & 63.15 \\
\hline Sun Hours (hr.) & 106.2 & 67.22 & 85.40 \\
\hline
\end{tabular}

\subsection{Parameters Measured}

Data on haematological, biochemical and hormonal profile were recorded. Blood samples from each bird were collected from the armpit (under the wing) of the bird for haematological and biochemical analysis using a sterilized disposable syringe and needles [15]. Blood samples were collected in the morning. A cotton swab soaked in methylated spirit was used to dilate the veins and to prevent infection. Blood samples were obtained by puncturing the brachial vein of the underside of the web of the wing of each of the hens using needles and syringes. An initial three (3) ml blood was taken into lablelled sterile universal bottle containing Ethylene-Diamine-Tetra-Acetic Acid (EDTA) as anticoagulant [15]. This was used to determine the haematological components within an hour of sample taken. Another three (3) ml of blood was collected from the same birds into labelled sterile sample bottle without anticoagulant and used to determine the biochemical components.

\subsubsection{Haematological parameters}

Haematological parameters were determined in full blood count (FBC) by using the Sysmex Haematological Auto-Analyser (Shenzhen Mindray Bio-medical electronics Co., Ltd, China) and included erythrocytes (Haemoglobin (Hb), Red blood cells (RBC), Mean Corpuscular Volume (MCV), Mean Corpuscular Haemoglobin (MCH), and Mean Corpuscular Haemoglobin Concentration (MCHC)) and Leukocytes and platelet (White blood cells, neutrophil, lymphocytes, eosinophil, basophil and platelet) [15].

\subsubsection{Biochemical parameters}

Biochemical parameters analyzed include total serum protein, albumin, globulin and cholesterol concentrations. The serum was used for the analysis as follows; the total protein (TP) was determined using Biuret method as described by Keller [16]. Blood albumin was determined using the Bromocresol Green (BCG) method [17]. Total cholesterol (TC) was estimated using the CHOP-PAP method and the globulin level was also calculated [17]. The globulin content was determined by subtracting albumin from the total protein [16]. Again, blood samples were obtained from birds by the 
same procedure mentioned above and drawn into plain vacutainer tubes to determine the triglyceride, High-density Lipoprotein (HDL), Low-density Lipoprotein (LDL) levels and glucose as described by Keller [16].

\subsubsection{Hormonal parameters}

The assay procedure was performed on Mindray ${ }^{\circledR}$ microplate reader $M R 96$ A (Shenzhen Mindray Bio-medical electronics Co., Ltd, China) and hormones determined included Progesterone, Estradiol, Prolactin, Luteinizing Hormone (LH) and Follicle Stimulating Hormone (FSH) [15].

\subsection{Data Analysis}

Data collected were analyzed using General Linear Model (GLM) procedure of Statistical Analysis System (SAS for Windows, version 7). The means were separated by using the probability of difference (PDIFF) procedure of SAS [18].

\section{Results}

\subsection{Proximate composition of moringa leaf meal}

Results of proximate composition of Moringa leaf meal (MOLM) are presented in Table 6. The proximate components of moringa leaf meal contains higher levels of crude protein (28.91 \%), metabolizable energy (8.55 Kcal/kg) and appreciable levels of crude fibre (13.34\%), dry matter (89.64 \%), ether extracts (5.32 \%), moisture (88.15\%), nitrogen free extracts $(43.85 \%)$ and total ash $(7.13 \%)$.

Table 6 Proximate composition of moringa leaf meal

\begin{tabular}{|l|c|c|}
\hline \multicolumn{1}{|c|}{ Attributes } & Percentage (\%) & Standard deviation \\
\hline Moisture & 88.15 & 0.05 \\
\hline Crude fibre & 13.34 & 0.08 \\
\hline Dry matter & 89.64 & 0.45 \\
\hline Ether extracts & 5.32 & 0.21 \\
\hline Crude protein & 28.91 & 0.21 \\
\hline Nitrogen Free Extracts & 43.85 & 0.11 \\
\hline Total Ash & 7.13 & 0.04 \\
\hline ME (Kcal/kg) & 8.55 & 0.07 \\
\hline
\end{tabular}

\subsection{Phytochemical properties in moringa leaf meal}

A phytochemical analysis was performed to determine the major class of compounds present in moringa leaf meal and the results are shown in Table 7. The results revealed the presence of high levels of chlorogenic acid as compared to all the other parameters. Kaempferol, quercetin and luteolin were observed to be moderate. However, apigenin was observed to be the lowest among all the parameters measured.

Table 7 Proximate composition of moringa leaf meal

\begin{tabular}{|l|c|c|}
\hline Parameter & $\boldsymbol{\mu g} / \mathbf{g}$ Dry matter & Standard deviation \\
\hline Apigenin & 25.37 & 2.19 \\
\hline Chlorogenic acid & 295.87 & 11.41 \\
\hline Kaempferol & 51.23 & 1.86 \\
\hline Luteolin & 45.36 & 2.02 \\
\hline Quercetin & 48.49 & 1.80 \\
\hline
\end{tabular}




\subsection{Effect of moringa leaf meal and season on erythrocytes and platelets}

The results of this study showed that moringa leaf meal had little or no effect $(\mathrm{P}>0.05)$ on the values of erythrocytes and platelets except mean cell volume and red blood cells $(\mathrm{P}<0.05)$ (Table 8). Mean values for mean cell volume was highest (175.39 fl) among Guinea fowls fed with diet containing $12 \%$ moringa leaf meal and lowest (163.93 fl) among birds fed with the control and $9 \%$ moringa leaf meal diets. Mean values for red blood cells were highest $\left(3.44 \times 10^{12} / L\right)$ among Guinea fowls fed with diet containing $15 \%$ moringa leaf meal and lowest $\left(2.51 \times 10^{12} / L\right)$ among birds fed with the control and $9 \%$ moringa leaf meal diets. The major and minor rainy seasons had the highest $(\mathrm{P}<0.05)$ mean cell haemoglobin and red blood cells, whilst the lowest haemoglobin and red blood cells values were recorded in the dry season. The highest $\left(23.69 \times 10^{9} / L\right)$ platelets value was recorded in the dry season whereas the major $\left(19.16 \times 10^{9} / L\right)$ and minor $\left(19.13 \times 10^{9} / \mathrm{L}\right)$ rainy seasons had the lowest mean values. Interactions of seasons with moringa leaf meal had little $(\mathrm{P}>0.05)$ effect on erythrocytes and platelets traits except mean cell volume $(\mathrm{P}<0.05)$.

Table 8 Effect of dietary moringa leaf meal and season on erythrocytes and platelets

\begin{tabular}{|c|c|c|c|c|c|c|c|}
\hline Variables & $\begin{array}{l}\mathrm{Hb} \\
(g / d L)\end{array}$ & $\begin{array}{l}\text { МCH } \\
(p g)\end{array}$ & $\begin{array}{l}\text { МСНС } \\
(g / d L)\end{array}$ & $\begin{array}{l}\text { MCV } \\
(f L)\end{array}$ & $\begin{array}{l}\text { PCV } \\
(\%)\end{array}$ & $\begin{array}{l}\text { Plat } \\
\left(x 10^{9} / L\right)\end{array}$ & $\begin{array}{l}\text { RBC } \\
\left(x 10^{12} / L\right)\end{array}$ \\
\hline \multicolumn{8}{|l|}{ Moringa leaf meal } \\
\hline 0\% MOLM & 11.08 & 62.53 & 42.31 & $163.93^{c}$ & 31.84 & 22.10 & $2.51^{\mathrm{c}}$ \\
\hline 9\% MOLM & 11.06 & 62.37 & 45.02 & $165.89 c$ & 33.87 & 20.66 & $2.60^{c}$ \\
\hline 12\% MOLM & 11.35 & 66.48 & 43.06 & $175.39^{a}$ & 34.94 & 20.54 & $2.87 \mathrm{~b}$ \\
\hline 15\% MOLM & 11.53 & 60.61 & 42.80 & $170.88^{b}$ & 34.59 & 19.34 & $3.44^{\mathrm{a}}$ \\
\hline SEM & 0.19 & 4.21 & 1.02 & 2.91 & 0.90 & 0.952 & 0.20 \\
\hline P-value & 0.2805 & 0.7927 & 0.2792 & 0.0381 & 0.0890 & 0.2600 & 0.0125 \\
\hline \multicolumn{8}{|l|}{ Season } \\
\hline Major Rainy Season & 11.26 & $71.12^{\mathrm{a}}$ & 43.33 & 169.03 & 34.33 & $19.16^{\mathrm{b}}$ & $3.04^{\mathrm{a}}$ \\
\hline Minor Rainy Season & 11.30 & $72.44^{\mathrm{a}}$ & 43.55 & 168.91 & 34.46 & $19.13^{\mathrm{b}}$ & $3.19^{\mathrm{a}}$ \\
\hline Dry Season & 11.21 & $45.44^{\mathrm{b}}$ & 43.01 & 169.13 & 32.64 & $23.69^{a}$ & $2.34 \mathrm{~b}$ \\
\hline SEM & 0.16 & 3.65 & 0.88 & 2.51 & 0.78 & 0.82 & 0.17 \\
\hline P-value & 0.9305 & $<.0001$ & 0.9088 & 0.9980 & 0.2031 & 0.0004 & 0.0036 \\
\hline
\end{tabular}

$\mathrm{abcd}=$ Means bearing different superscripts in the same column are significantly different $(\mathrm{P}<0.05) ;{ }^{*}=\mathrm{p}<0.05$, ns =not significant, \% = Percent; MOLM = Moringa Leaf Meal; S. E = Standard error of means; P = probability of main effects; Dry S= Dry Season; Maj. R. S. = Major Rainy Season; Min. R. S. = Minor Rainy Season, Hb=Haemoglobin; MCV = Mean cell volume; MCH= Mean cell haemoglobin; MCHC= Mean cell haemoglobin concentration; PCV= Packed cell volume; Plat= Platelets; RBC = Red blood cells.

\subsection{Effect of dietary moringa leaf meal and season on leukocytes}

Dietary moringa leaf meal had influence $(\mathrm{P}<0.05)$ on eosinophil and white blood cells $(\mathrm{WBC})($ Table 9$)$. Eosinophil level was highest $\left(3.95 \times 10^{9} / \mu l\right)$ among Guinea fowls fed with diet that containing $9 \%$ MOLM and lowest $\left(2.06 \times 10^{9} / \mu l\right)$ among birds fed with the control diet. Birds fed with diet contained 9, 12 and $15 \%$ MOLM had similar mean values for white blood cells and these were higher than that of the control. Season of production had positive effect $(\mathrm{P}=0.01)$ on basophil levels. However, no significant $(\mathrm{P}>0.05)$ effect was observed in all the other parameters. The highest $\left(2.00 \times 10^{9} / \mu l\right)$ basophil level was produced in the major rainy season and was followed by minor rainy season $\left(1.56 \times 10^{9} / \mu \mathrm{l}\right)$. The dry season had the lowest $\left(1.37 \times 10^{9} / \mu l\right)$ basophil levels (Table 9). Dietary moringa leaf meal $\times$ season interaction did not show significant $(\mathrm{P}>0.05)$ effect on all leukocyte's parameters. 
Table 9 Effect of moringa leaf meal and season on leukocytes

\begin{tabular}{|c|c|c|c|c|c|c|}
\hline Variables & $\begin{array}{c}\text { Bas } \\
\left(\times 10^{9} / \mu l\right)\end{array}$ & $\begin{array}{c}\text { Eos } \\
\left(x 10^{9} / \mu l\right)\end{array}$ & $\begin{array}{c}\text { Lymph } \\
\left(\times 10^{9} / \mu l\right)\end{array}$ & $\begin{array}{c}\text { Mon } \\
\left(x 10^{9} / \mu l\right)\end{array}$ & $\begin{array}{c}\text { Neu } \\
\left(x 10^{9} / \mu l\right)\end{array}$ & $\begin{array}{c}\text { WBC } \\
\left(x 10^{9} / L\right)\end{array}$ \\
\hline \multicolumn{7}{|l|}{ Moringa leaf meal } \\
\hline 0\% MOLM & 1.83 & $2.06^{c}$ & 46.41 & 4.53 & 47.00 & $158.80^{\mathrm{b}}$ \\
\hline 9\% MOLM & 1.83 & $3.95^{\mathrm{a}}$ & 42.28 & 6.04 & 47.65 & $166.29^{a}$ \\
\hline $12 \%$ MOLM & 1.33 & $2.70^{\mathrm{b}}$ & 46.97 & 5.16 & 45.09 & $167.13^{\mathrm{a}}$ \\
\hline 15\% MOLM & 1.58 & $2.40^{\mathrm{b}}$ & 48.47 & 4.16 & 46.73 & $167.12^{\mathrm{a}}$ \\
\hline SEM & 0.16 & 0.32 & 3.25 & 0.50 & 2.93 & 2.51 \\
\hline P-value & 0.1035 & 0.0014 & 0.5813 & 0.0673 & 0.9370 & 0.0218 \\
\hline \multicolumn{7}{|l|}{ Season } \\
\hline Major Rainy Season & $2.00^{\mathrm{a}}$ & 2.75 & 47.23 & 4.96 & 45.68 & 161.63 \\
\hline Minor Rainy Season & $1.56^{\mathrm{b}}$ & 2.75 & 47.23 & 4.96 & 45.68 & 161.29 \\
\hline Dry Season & $1.37^{c}$ & 2.83 & 43.63 & 5.02 & 48.50 & 164.73 \\
\hline SEM & 0.13 & 0.27 & 2.81 & 0.43 & 2.54 & 2.17 \\
\hline P-value & 0.0099 & 0.9757 & 0.5863 & 0.9916 & 0.6687 & 0.4775 \\
\hline
\end{tabular}

$\mathrm{abc}=$ Means bearing different superscripts in the same column are significantly different $(\mathrm{p}<0.05) ;{ }^{*}=\mathrm{p}<0.05$, ns =not significant, \% $\%$ Percent; MOLM = Moringa Leaf Meal; S. E = Standard error of means; $\mathrm{P}=$ probability of main effects; Dry S= Dry Season; Maj. R. S. = Major Rainy Season; Min R. S. = Minor Rainy Season, Bas = Basophil; Eosi = Eosinophil; Lymph= Lymphocytes; Mon=Monocytes; Neu= Neutrophil; WBC=White blood cell.

\subsection{Effect of dietary moringa leaf meal and season on biochemical parameters}

Triglycerides, high density lipoprotein and low-density lipoprotein levels increased $(\mathrm{P}<0.05)$ with increasing levels of dietary MOLM (Table 10). However, all other biochemical parameters measured were not $(\mathrm{P}>0.05)$ affected.

Table 10 Effect of moringa leaf meal and season on biochemical parameters

\begin{tabular}{|c|c|c|c|c|c|c|c|}
\hline Variables & $\begin{array}{l}\text { Alb } \\
(g / L)\end{array}$ & $\begin{array}{l}\text { Chol } \\
(\mathrm{mmol} / \mathrm{l})\end{array}$ & $\begin{array}{l}\text { Glob } \\
(g / L)\end{array}$ & $\begin{array}{l}\text { HDL } \\
(\mathrm{mmol} / \mathrm{l})\end{array}$ & $\begin{array}{l}\text { LDL } \\
(\mathrm{mmol} / \mathrm{l})\end{array}$ & $\begin{array}{l}\text { TRIG } \\
(\mathrm{mmol} / \mathrm{l})\end{array}$ & $\begin{array}{l}\text { TSP } \\
(g / L)\end{array}$ \\
\hline \multicolumn{8}{|l|}{ Moringa leaf meal } \\
\hline $0 \%$ MOLM & 19.84 & 3.98 & 31.75 & $1.51^{\mathrm{d}}$ & $1.73^{\mathrm{d}}$ & $0.81^{\mathrm{a}}$ & 49.10 \\
\hline 9\% MOLM & 18.67 & 3.84 & 31.17 & $1.99 \mathrm{c}$ & $2.41^{\mathrm{c}}$ & $0.66^{\mathrm{b}}$ & 49.86 \\
\hline 12\% MOLM & 16.77 & 3.78 & 26.70 & $2.37^{\mathrm{b}}$ & $2.89^{b}$ & $0.65^{b}$ & 43.48 \\
\hline 15\% MOLM & 16.90 & 3.69 & 31.20 & $2.58^{\mathrm{a}}$ & $3.21^{\mathrm{a}}$ & $0.55^{c}$ & 48.11 \\
\hline SEM & 1.43 & 0.08 & 1.70 & 0.12 & 0.44 & 0.13 & 2.36 \\
\hline P-value & 0.3810 & 0.1052 & 0.1472 & $<.0001$ & $<.0001$ & 0.013 & 0.2429 \\
\hline Season & $\begin{array}{c}\text { Alb } \\
(g / L)\end{array}$ & $\begin{array}{c}\text { Chol } \\
(\mathrm{mmol} / \mathrm{l})\end{array}$ & $\begin{array}{l}\text { Glob } \\
(g / L)\end{array}$ & $\begin{array}{c}\text { HDL } \\
(\mathrm{mmol} / \mathrm{l})\end{array}$ & $\begin{array}{c}\text { LD } \\
(\mathrm{mmol} / \mathrm{l})\end{array}$ & $\begin{array}{c}\text { TRIG } \\
(\mathrm{mmol} / \mathrm{l})\end{array}$ & $\begin{array}{c}\text { TSP } \\
(g / L)\end{array}$ \\
\hline Major Rainy Season & $19.77^{\mathrm{a}}$ & $4.09^{\mathrm{a}}$ & $28.57^{\mathrm{b}}$ & $2.44^{\mathrm{a}}$ & $2.88^{\mathrm{a}}$ & $0.78^{\mathrm{a}}$ & 47.41 \\
\hline Minor Rainy Season & $19.77^{\mathrm{a}}$ & $3.89^{\mathrm{b}}$ & $28.57^{b}$ & $2.11^{\mathrm{b}}$ & $2.17^{\mathrm{b}}$ & $0.65^{b}$ & 47.41 \\
\hline Dry Season & $14.60^{\mathrm{b}}$ & $3.50^{c}$ & $33.49^{\mathrm{a}}$ & $1.75^{\mathrm{c}}$ & $1.89^{c}$ & $0.52^{c}$ & 48.09 \\
\hline SEM & 1.24 & 0.07 & 1.47 & 0.14 & 0.55 & 0.11 & 2.04 \\
\hline P-value & 0.0073 & $<.0001$ & 0.0349 & $<.0001$ & $<.0001$ & 0.0014 & 0.9638 \\
\hline
\end{tabular}

$\mathrm{abc}=$ Means bearing different superscripts in the same column are significantly different $(\mathrm{P}<0.05)$; $^{*}=\mathrm{p}<0.05$, ns =not significant, \% $=$ Percent; MOLM = Moringa Leaf Meal; S. E = Standard error of means; P = probability of main effects; Dry S = Dry Season; Maj. R. S. = Major Rainy Season; Min. R. S. = Minor Rainy Season, Alb=Albumin; Chol= Cholesterol; Glob = Globulin; TSP= Total serum protein, TRIG = Triglycerides; HDL = High Density Lipoprotein; LDL = Low Density Lipoprotein. 
Mean values for total serum protein observed was not influenced by season $(\mathrm{P}=0.2429)$. The mean albumin values observed was similar $(\mathrm{P}>0.05)$ in both major and minor rainy seasons which was significantly $(\mathrm{P}=0.0073)$ higher than that in the dry season. Season had significant $(\mathrm{P}<0.05)$ effect on cholesterol and globulin levels. Cholesterol, triglycerides, high density lipoprotein and low-density lipoprotein levels were highest in the major rainy season, followed by minor rainy season and lowest in the dry season in that order. The highest $(\mathrm{P}<0.05)$ value for globulin was observed in the dry season and similar in both major and minor rainy seasons. Dietary moringa leaf meal $\times$ season interaction did not show significant $(\mathrm{P}>0.05)$ effect on all biochemical parameters observed.

\subsection{Effect of dietary moringa leaf meal and season on hormonal levels}

Progesterone and oestrogen were extracted from females only while testosterone was extracted from males only. However, all other traits were observed from males and females. Different levels of moringa leaf meal showed little or no effect $(\mathrm{P}>0.05)$ on hormonal levels considered in this study except progesterone $(\mathrm{P}=0.0025)$ (Table 11). The highest level of progesterone was observed among birds fed with diet containing 12 and $15 \%$ moringa leaf meal inclusion levels and lowest among birds on the control diet. Seasonal variation influenced $(\mathrm{P}<0.05)$ the levels of follicle stimulating hormone, luteinizing hormone, oestrogen and prolactin. However, no positive $(\mathrm{P}>0.05)$ effect was observed for both progesterone and testosterone. The highest mean values for follicle stimulating hormone, luteinizing hormone and prolactin were observed in the dry season. Oestrogen level was highest $(\mathrm{P}=0.0042)$ in the major $(45.40 \mathrm{pg} / \mathrm{ml})$ and minor $(48.46 \mathrm{pg} / \mathrm{ml})$ rainy seasons and lowest $(27.80 \mathrm{pg} / \mathrm{ml})$ in the dry season. Interactions of different levels of dietary moringa leaf meal with seasons were important to influence $(\mathrm{P}<0.05)$ the level of prolactin. However, interactions on all other traits were not significant $(\mathrm{P}>0.05)$

Table 11 Effect of moringa leaf meal and season on hormonal parameters

\begin{tabular}{|c|c|c|c|c|c|c|}
\hline Variables & $\begin{array}{l}\text { FSH } \\
(I U / m l)\end{array}$ & $\begin{array}{l}\text { LH } \\
(I U / m I)\end{array}$ & $\begin{array}{l}\text { Oestrogen } \\
(\mathrm{pg} / \mathrm{ml})\end{array}$ & $\begin{array}{l}\text { Prog } \\
(n g / d l)\end{array}$ & $\begin{array}{l}\text { Prolactin } \\
(n g / m l)\end{array}$ & $\begin{array}{l}\text { Testosterone } \\
(n g / d l)\end{array}$ \\
\hline \multicolumn{7}{|l|}{ Moringa leaf meal } \\
\hline 0\% MOLM & 0.47 & 0.67 & 33.25 & $1.37 \mathrm{c}$ & 12.38 & 1.91 \\
\hline 9\% MOLM & 0.55 & 0.73 & 44.08 & $2.99 \mathrm{~b}$ & 11.36 & 1.60 \\
\hline $12 \%$ MOLM & 0.61 & 0.81 & 45.07 & $3.04^{\mathrm{a}}$ & 9.22 & 1.96 \\
\hline 15\% MOLM & 0.58 & 1.72 & 39.80 & $3.28^{a}$ & 10.10 & 2.14 \\
\hline SEM & 0.09 & 0.60 & 5.05 & 0.36 & 0.97 & 0.38 \\
\hline P-value & 0.7104 & 0.5744 & 0.3505 & 0.0025 & 0.1290 & 0.7996 \\
\hline \multicolumn{7}{|l|}{ Season } \\
\hline Major Rainy Season & $0.34^{\mathrm{b}}$ & $0.41^{b}$ & $45.40^{\mathrm{a}}$ & 2.97 & $8.39 \mathrm{~b}$ & 1.86 \\
\hline Minor Rainy Season & $0.34^{\mathrm{b}}$ & $0.41^{\mathrm{b}}$ & $48.46^{\mathrm{a}}$ & 3.01 & $8.39 \mathrm{~b}$ & 1.86 \\
\hline Dry Season & $0.98^{\mathrm{a}}$ & $2.13^{\mathrm{a}}$ & $27.80^{\mathrm{b}}$ & 2.03 & $15.52^{\mathrm{a}}$ & 1.99 \\
\hline SEM & 0.07 & 0.52 & 4.37 & 0.31 & 0.84 & 0.33 \\
\hline P-value & $<.0001$ & 0.0394 & 0.0042 & 0.0568 & $<.0001$ & 0.9515 \\
\hline
\end{tabular}

abcd= Means bearing different superscripts in the same column are significantly different $(\mathrm{P}<0.05) ;{ }^{*}=\mathrm{p}<0.05$, ns $=$ not significant, $\%=$ Percent; MOLM = Moringa Leaf Meal; S. E = Standard error of means; P = probability of main effects; Dry S= Dry Season; Maj. R. S = Major Rainy Season; Min. R. $\mathrm{S}=$ Minor Rainy Season, FSH = Follicle Stimulating Hormone; LH = Luteinizing Hormone; Prog = Progesterone

\subsection{Effect of dietary moringa leaf meal and season on metabolites}

The effect of different levels of moringa leaf meal on metabolites is presented in Table 12. Different levels of moringa leaf meal showed no significant $(\mathrm{P}>0.05)$ effect on calcium, chlorine and potassium levels. However, significant $(\mathrm{P}<0.05)$ effect was observed on sodium. The highest (166.69 $\mathrm{nmol} / \mathrm{l}$ ) level of sodium was observed among birds fed with diet that contained $12 \%$ MOLM and lowest (154.84 nmol/l) among birds fed with diet containing $9 \%$ moringa leaf meal. The control and $15 \%$ MOLM treatments had similar ( $>0.05)$ sodium levels. The levels of chlorine and potassium were influenced $(\mathrm{P}<0.05)$ by seasonal variation. However, calcium and sodium levels were not affected by seasonal variation (Table 12). The highest level of chlorine was observed in the dry season and lowest in the major and minor rainy 
seasons. Potassium level was significantly $(\mathrm{P}<0.05)$ highest in the major rainy season followed by minor rainy season and lowest in the dry season. Interactions of seasons with moringa leaf meal had no influence $(\mathrm{P}>0.05)$ on metabolites except $(\mathrm{P}<0.05)$ potassium.

Table 12 Graded levels of moringa leaf meal and season on metabolites

\begin{tabular}{|c|c|c|c|c|}
\hline Variables & $\mathrm{Ca}^{2+}(\mathrm{nmol} / \mathrm{L})$ & $\mathrm{Cl}^{-}(\mathrm{nmol} / \mathrm{L})$ & $\mathrm{K}^{+}(\mathrm{nmol} / \mathrm{L})$ & $\mathrm{Na}^{+}(\mathrm{nmol} / \mathrm{L})$ \\
\hline \multicolumn{5}{|l|}{ Moringa leaf meal } \\
\hline 0\% MOLM & 4.00 & 112.18 & 3.80 & $158.79 \mathrm{~b}$ \\
\hline 9\% MOLM & 4.40 & 113.40 & 4.21 & $154.84^{c}$ \\
\hline 12\% MOLM & 4.67 & 114.66 & 4.19 & $166.69^{a}$ \\
\hline 15\% MOLM & 3.96 & 107.52 & 3.55 & $159.30^{\mathrm{b}}$ \\
\hline SEM & 0.22 & 2.65 & 0.20 & 1.98 \\
\hline P-value & 0.0960 & 0.2656 & 0.0771 & 0.0018 \\
\hline \multicolumn{5}{|l|}{ Season } \\
\hline Major Rainy Season & 4.40 & $108.37^{b}$ & $4.77^{\mathrm{a}}$ & 161.00 \\
\hline Minor Rainy Season & 4.31 & $108.52^{\mathrm{b}}$ & $4.35^{b}$ & 159.35 \\
\hline Dry Season & 4.06 & $118.93^{\mathrm{a}}$ & $2.70^{c}$ & 159.37 \\
\hline SEM & 0.19 & 2.29 & 0.17 & 1.71 \\
\hline P-value & 0.4469 & 0.0030 & $<.0001$ & 0.7411 \\
\hline
\end{tabular}

$\mathrm{abc}=$ Means bearing different superscripts in the same column are significantly different $(\mathrm{P}<0.05) ;{ }^{*}=\mathrm{p}<0.05, \mathrm{~ns}=$ not significant, $\%=$ Percent MOLM = Moringa Leaf Meal; S. E = Standard error of means; P = probability of main effects; Dry S = Dry Season; Maj. R. S = Major Rainy Season; Min. R. $\mathrm{S}=$ Minor Rainy Season, $\mathrm{Ca}=$ Calcium; $\mathrm{Cl}=$ Chlorine; $\mathrm{K}=$ Potassium; $\mathrm{Na}=$ Sodium.

\section{Discussion}

\subsection{Proximate composition and phytochemical properties of moringa leaf meal}

Generally, moringa leaf meal was found to contain considerable protein (28.91) (Table 6). This value is higher than the value of $17.01 \%$ and $23 \%$ reported by Ogbe and Afiku [19] and Makkar and Becker [20] respectively. However, the result is comparable to the $27.44 \%$ reported by Olugbemi et al. [21] and $28.50 \%$ reported by Kwafo et al. [22] but lower than the $30.65 \%$ obtained by Mutayoba et al. [23]. The protein value (28.91) recorded in this study indicates that the nutrient content of the moringa gives an indication of its usefulness as an important feed resource for feeding Guinea fowls. The crude fibre value of $13.34 \%$ obtained in this study appears lower than the $16.11 \%$ reported by Richter et al. [24] but was higher than $13.05 \%$ and $10.59 \%$ obtained by Kwafo et al. [22] and Abbas et al. [25]. The crude fibre value obtained in this study is an indication that adding MOLM to the diet of Guinea fowls will not affect digestibility. The value for dry matter (89.64 \%) was observed to be lower than the 90.21 obtained by Kwafo et al. [22] but was higher than $86 \%$ reported by Kakengi et al. [26]. The values obtained for ether extracts (5.23\%), moisture (88.15\%), nitrogen free extracts $(43.85 \%)$ and total ash $(7.13 \%)$ were similar to values obtained in previous studies $[19,21,25]$.

Results on phytochemical properties of this study are consistent with those reported by Valdez-Solana et al. [27] who reported high levels of chlorogenic acid (286.13 $\pm 15.09 \mu \mathrm{g} / \mathrm{g})$, kaempferol $(46.43 \pm 2.14 \mu \mathrm{g} / \mathrm{g})$, quercetin $(46.18 \pm 0.6$ $\mu \mathrm{g} / \mathrm{g})$ and luteolin $(44.56 \pm 2.03 \mu \mathrm{g} / \mathrm{g})$. The levels of phytochemicals observed in this study indicate that the levels of lipids in the liver and plasma will be low and will not have any negative effect on the health status of the birds. Previous phytochemical investigations have identified quercetin and kaempferol phytochemicals in moringa leaf meal [28]. Though MOLM is known to contain quercetin and kaempferol however, traceable amounts of chlorogenic acid and derivatives have been detected within the leaves from Ghana, Senegal, and Zambia [8]. Chlorogenic acid and its isomers are esters of quinic and caffeic acids that have abilities to inhibit oxidation and also promote various pharmacological activities such as antiobesity, reduction of plasma and liver lipids, and inhibition of acute lung injury [9]. The levels of phytochemical properties in moringa leaves influences the production of hormones as reported by AbouSekken [9]. 


\subsection{Effect of dietary moringa leaf meal and season on erythrocytes and platelets}

The mean cell volume and red blood cells values recorded in this study compared to standard values in birds. Similarly, the RBC values of birds observed in this study fall within the normal reference range (1.85-3.5) reported by Aengwanich et al. [29]. The highest $(\mathrm{P}<0.05)$ mean values for mean cell volume and red blood cells observed in the dietary moringa leaf meal as compared to the control diet could be explained that moringa leaves are excellent source of vitamin B [30, 31], calcium, protein, potassium and essential micronutrients with antioxidant activity - Selenium which influences cell volume and the production of more red blood cells in farm animals [30]. Red Blood Cells (RBC) are responsible for the transportation of oxygen and carbon dioxide in the blood as well as manufacture of haemoglobin hence, higher $(\mathrm{P}=$ 0.0125) values observed in this study (Table 8) indicate a greater potential for this function and a better state of health among Guinea fowls fed with dietary MOLM as compared with Guinea fowls fed the control diet. The results of this study again demonstrated that Guinea fowl birds fed with dietary moringa leaf meal indicate greater potential for the transportation functions and hence such birds could be predicted to be healthy as compared to birds on the control treatment. According to Amevor [31] the major role of red blood cells is to transport oxygen from the lungs of the birds to the body tissues and transport carbon dioxide from the tissue to the lungs of the bird. In general, the higher levels of mean cell volume and red blood cells values observed in this study corroborates with the findings of [32, 33] who reported that birds supplemented with moringa leaf meal had improved levels of mean cell volume and red blood cells.

Highest $(\mathrm{P}<0.05)$ mean cell haemoglobin and red blood cells during minor rainy season could be attributed to the favourable environmental conditions. The importance of maintaining a comfortable and stress-free environment for Guinea fowls cannot be underestimated. Favourable environmental conditions remove excess heat in the pens thereby reducing the rate at which birds are exposed to heat stress. Similarly, Ashizawa and Sano [34] and Korankye et al. [35] reported that, the season of production had significant improvement on cell haemoglobin, lymphocyte, monocytes and red blood cells. The result of this study corroborates with the findings of Tutubalang [36] who observed enhanced mean cell volume, WBC and red blood cells in Potchefstroom koekoek indigenous chicken. Platelet was observed to be higher in the dry season and this could be attributed to the higher temperature recorded in the dry season. This could be explained that temperatures above $30^{\circ} \mathrm{C}$ cause marked activation of platelets in birds leading to higher production in the dry season. This result agrees with the observation made by Aderinola [37] who reported that birds supplemented with moringa leaf meal had better feed conversion ability in the dry season hence had higher values for platelets and PCV. Results of the study agree with earlier report that hot and cold periods exert detrimental effect on mean cell haemoglobin and red blood cells [38, 39].

\subsection{Effect of moringa leaf meal and season on leukocytes}

In both human and animals, WBC produces antibodies in the blood which help in the development of immunity thus, protecting the body against disease causing microorganisms [40,41]. Eosinophil is also responsible for strong immunity which protects birds against diseases and infections. The increase in eosinophil and white blood cells observed among the moringa leaf meal diets as compared to the control treatment could be explained that dietary moringa leaf meal increased the levels of all the necessary essential nutrients needed for rapid growth and body building which protect birds against infections. In general, the higher level of eosinophil and white blood cells values observed in this study corroborates with the findings of Mohan et al. [32].

Basophil was higher during the major rainy season followed by minor rainy season and lower in the dry season. This could be explained that moderate ambient temperature enhances maximum production of gonadotropin hormones which stimulate basophil production hence; this is possibly during the major rainy season where temperatures are relatively low as compared to the dry season. The results of this study corroborate with the findings of Elagib et al. [42] who reported higher levels of epithelial cells and basophil in cold seasons as compared to the dry seasons.

\subsection{Effect of dietary moringa leaf meal and season on biochemical parameters}

The improvement in the levels of triglycerides, high density lipoprotein and low-density lipoprotein indicates that the diet was relatively of good quality and that birds fed the diet were more efficient in protein metabolism and utilization. The high- and low-density lipoprotein values observed with increasing levels of dietary moringa leaf meal reflects the protein levels in the test diets. The values of triglycerides in the dietary treatments numerically decreased from 0.810.13 as the MOLM inclusion level increased in the diet. This showed that the Guinea fowls fed with dietary moringa leaf meal efficiently utilized the carbohydrate content of the diets. These findings are in line with the work done by Kout $e t$ al. [43] who stated that the total protein was significantly improved in both the control and MOLM treated diets $(2 \%, 4$ $\%$ and $6 \%$ MOLM). 
The non-significant differences observed on other biochemical traits could be explained that the presence of polyphenols and flavonoids in moringa leaf meal affect tissue bio-efficiency and metabolites in birds which affect biochemical traits [44]. The biochemical values obtained in this study compared to standard values in birds. Similar findings were reported by Makanjuola et al. [45] who reported that $0.2 \%, 0.4 \%$ and $0.6 \%$ moringa leaf meal inclusion in the diet did not influence the serum total protein, albumin and globulin. Amevor [31] also reported that, moringa leaf meal showed no significant effect on cholesterol and triglyceride levels. However, the author observed significant effect on albumin, globulin, total serum protein, high density lipoprotein and low-density lipoprotein. The result is also in agreement with $[29,46]$ who reported no significant effect on albumin, cholesterol, globulin and triglyceride levels.

The result of this study corroborates with earlier studies conducted by Nalubamba et al. [47] who observed highest levels of cholesterol, triglycerides, high density lipoprotein and low-density lipoprotein levels during the rainy season and lowest in the dry season. This is because during the rainy season, moringa leaf meal contained high levels of essential plant nutrients as compared to the dry season, hence when fed to birds there was high improvement in biochemical parameters. The results of this study corroborate with the findings of Elagib et al. [42] who reported significant effect of season on albumin and cholesterol levels. Research conducted by Yokus et al. [48]; Jesuyon and Salako [49] indicates that mean values for total protein, albumin, and globulin had been found to be significantly lower due to exposure of the animals to high ambient temperature thereby affecting the biochemical traits in birds. According to the reports of Korankye et al. [35] plasma total proteins decreased significantly when laying hens were exposed to above $36{ }^{\circ} \mathrm{C}$ environmental temperature than moderate temperature regime. This finding agrees with the report made by Elaroussi [50] who reported that at higher temperatures, plasma albumin decreased significantly during hot seasons and may be attributable to changes in body temperature that causes a shift in tissue fluids and thus cause a change in the concentration of plasma proteins.

\subsection{Effect of dietary moringa leaf meal and season on hormonal parameters}

Birds fed with diet that contained $15 \%$ MOLM had the highest progesterone secretion level possibly due to high levels of phytochemicals in the diet. The level of progesterone secretion in this study is similar to the report of Renema et al. [51] on broiler hens fed diet that contained graded levels of MOLM. According to the work done by Bocchinfuso and Hammond [52], high levels of amino acids in the diet trigger high levels of steroid hormones such as progesterone production in the body during the breeder stage. The results of this study showed no significant increase in follicle stimulating hormone, luteinizing hormone, oestrogen, prolactin and testosterone. This corroborates with earlier report of Becker [53] that dietary moringa leaf meal consumption had no direct relationship with follicle stimulating hormone, luteinizing hormone, oestrogen, prolactin and testosterone concentration in female in the reproductive stage. The results are also in agreement with the report made by $[29,46]$ that there was no significant effect on follicle stimulating hormone, luteinizing hormone and oestrogen.

Seasonal variations in poultry production and reproductive activities are generally associated with gonadotropin secretion, especially follicle stimulating hormone, luteinizing hormone and prolactin [54]. In this study, higher levels of follicle stimulating hormone, luteinizing hormone and prolactin were observed in the dry season where there is adequate sunshine and long day length. According to the report made by Balog et al. [55] at higher temperatures and long day length there is high rate of gonadotropin secretion as compared to the rainy seasons in birds. Dunn and Sharp [56] reported that when male quails were transferred from short day length to long day lengths, the level of gonadotropins rose substantially during the first week of photo stimulation, testicular growth and steroid genesis begin and maturity reached as compared to short day lengths. This indicates that long day length enhances steroid genesis leading to high production of follicle stimulating hormone and luteinizing hormone.

\subsection{Effect of dietary moringa leaf meal and season on metabolites}

Dietary MOLM significantly influenced $(\mathrm{P}<0.05)$ sodium secretion but had little effect on calcium, chlorine and potassium levels. Birds fed with $12 \%$ MOLM had the highest $(\mathrm{P}<0.05)$ level of sodium. The level of sodium observed in this study is higher than the normal serum sodium values which range from 135 to $145 \mathrm{nmol} / \mathrm{L}$. The result indicates that the birds were very healthy. Sodium is the major extracellular cation which regulates the total amount of water in the body [57]. Reduction in sodium levels in birds, results in decrease in osmotic pressure and consequent disturbance of acid-based balance in the body. Sodium deficiency results in heart failure, decreased blood pressure and increased hematocrit and decreased elasticity of subcutaneous tissue as well as low adrenal gland function leading to elevated levels of uric acid in the blood and subsequent shock and death [58]. The result is in agreement with the report obtained by $[29,46]$ who reported no significant effect on calcium and potassium levels. However, the authors reported significant effect on sodium levels. 
Seasonal variations in poultry production and reproductive activities are generally associated with hormonal and metabolites secretion [54]. In this study, higher levels of chlorine and potassium were observed in the cold seasons where temperatures were relatively low indicating that cold temperature increased feed intake and feed utilization which increased elasticity of subcutaneous tissue as well as high adrenal gland functioning in the body. Currently, there is limited literature on the effect of season on metabolites.

\subsection{Interaction effects of fixed factors on blood and hormonal profile of the Pearl Guinea fowl}

Moringa leaf meal $\times$ season interactions observed on mean cell volume, prolactin and potassium $\left(\mathrm{K}^{+}\right)$in this study suggest that the combine sets of the two factors should be considered in farm animal genetic improvement. This means that in the absence of moringa leaf meal $\times$ season interactions the blood components of the Guinea fowls will be underestimated. Interactions on all other traits had no considerable effect. There has never been a study of moringa leaf meal and season interaction on blood profile of the Guinea fowl. The importance of interactions of season and age factors has been recognized in farm animal genetic improvement. Age $\times$ season interaction was found to be significant on white blood cells, red blood cells, mean cell volume and prolactin of white leghorn [42].

\section{Conclusion}

This study concludes that Guinea fowls fed with diet containing $12 \%$ and $15 \%$ moringa leaf meal increased red blood cells, mean cell volume and sodium levels. Guinea fowls fed with diet containing $9 \%$ moringa leaf meal produced more eosinophil. Increasing dietary moringa leaf meal in the diet of Guinea fowls increased the production of progesterone. Minor rainy season recorded the best mean cell haemoglobin and red blood cells in the blood. Platelets, globulins, follicle stimulating hormone, luteinizing hormone, prolactin and chlorine production were highest in the dry season. Major rainy season stimulated higher production of basophil, cholesterol and potassium levels. Mean cell volume, prolactin and potassium levels were influenced by the interaction effects of moringa leaf meal and season.

\section{Recommendation}

This study recommends that farmers and breeders should consider $15 \%$ dietary MOLM inclusion level for optimum productivity. This study further recommends that Guinea fowl health management should be intensified in the major and minor rainy seasons to avert health challenges resulting from seasonal variations especially, during the brooding stage to reduce keet mortalities

\section{Compliance with ethical standards}

\section{Acknowledgments}

The authors are grateful to the Department of Animal Science Education, Faculty of Agriculture Education, University of Education, Winneba for providing facilities for this study.

\section{Disclosure of conflict of interest}

Authors have declared that no conflict of interests exists.

\section{References}

[1] Moreki JC, Seabo D. Guinea Fowl Production in Botswana. Journal of World's Poultry Research. 2012. 2(1): 1-4.

[2] Ayeni JSO. Studies of grey breasted Guinea fowl (Numida meleagris galeatapallas) in Nigeria. World's Poultry Science Journal. 1983; 39: 143-151.

[3] Adam M. The Constraints and the Prospects for Guinea fowl Production in the Northern Region of Ghana. B.Sc. Dissertation, Faculty of Agriculture, University for Development Studies, Tamale, Ghana. 1997.

[4] Konlan SP, Avornyo FK.The effect of wetland on Guinea fowl egg productivity and fertility during the dry season in the guinea ecological zone of Ghana. Sky Journal of Agricultural Research. 2013; 2(9): 126-131.

[5] Moreki JC. Guinea Fowl Production. Reach Publishers, Wands beck, South Africa. 2009; 7-31.

[6] Kyere CG, Annor SY, Kagya-Agyemang JK, Korankye O. Effect of egg size and day length on reproductive and growth performance, egg characteristics and blood profile of the Guinea fowl. Livestock Research for Rural Development. 2017; 29. 
[7] Odetola OM, Adetola O0, Ijadunola TI, Adedeji OY, Adu OA. Utilization of moringa (Moringa oleifera) leaves meal as a replacement for soya bean meal in rabbit's diets, Scholarly Journal of Agricultural Science. 2012; 2: 309-313.

[8] Ogbe AO. Effect of polyherbal aqueous extracts (Moringa oleifera, gumarabic and wild Ganoderma lucidum) in comparison with antibiotic on growth performance and haematological parameters of broiler chickens. Research Journal for Recent Sciences. 2012; 1(7): 10-18.

[9] AbouSekken MSM. Performance, Immune response and carcass quality of broilers fed low protein diets contained either Moringa oleifera leaves meal or its extract. Journal of American Science. 2015; 153-164.

[10] Ghana Districts. Ghanadistricts.net. 2006.

[11] Meteorological Services Department (MSD) Annual Reports. Mampong Municipal Assembly, Mampong-Ashanti, Ashanti Region, Ghana. 2017.

[12] Meteorological Services Department (MSD) Annual Reports. Mampong Municipal Assembly, Mampong-Ashanti, Ashanti Region, Ghana. 2018.

[13] Ghana Meteorological Agency. 2017 and 2018; Climatology.

[14] National Research Council (NRC). Nutrient requirement of poultry. Ninth revised Edition. National Academic Press, Washington D.C., USA. 2006; 155.

[15] Hauptmanova K, Maly M, Literak I. Haematology and Leukocytozoonosis of Great Tits (Parus major) during winter. Acta Veterinaria Brunensis. 2002; 71: 199-204.

[16] Keller A. Total Serum Protein Determination. Clinical Chemistry, Theory, Analysis and Correlation. St. Lious, Mosby Company, USA. 1984.

[17] Sharp PJ. Lighting Pattern and Persistency of Lay InOke, U. K., Hebert, U. and Akinmutimi, A. H. Early Lay Characteristics and Haematology of Pearl Guinea Fowls as Influenced by Dietary Protein and Energy Levels. London Agriculture and Food Research council. 1988; 10-11.

[18] Statistical Analysis System (SAS). User's Guide. SAS/STAT® 9.2, Cary, NC: SAS Institute Inc. 2008.

[19] Ogbe AO, Affiku JP. Proximate study, mineral and anti-nutrient composition of Moringa oleifera leaves harvested from Lafia, Nigeria: Potential benefits in poultry nutrition and health. Journal of Microbiology, Biotechnology and Food Sciences. 2012; 1: 296-308.

[20] Makkar H, Becker K. Effects of dietary tannic acid and quebracho tannin on growth performance and metabolic rates of common carp. Journal of Aquaculture. 1999; 175: 327-335.

[21] Olugbemi TS, Mutayoba SK, Lekule FP. Moringa oleifera leaf meal as a hypocholesterolemic agent in laying hen diets. Journal ofLivestock Research for Rural Development. 2010; 22(4): 363-367.

[22] Kwafo S, Kagya-Agyemang JK, Annor SY, Bonsu FRK. Growth Performance, Blood Profile and Economic Efficiency of Layer Chicks Fed Diets Containing Graded Levels of Moringa Leaf Meal at Pre-Laying Phase. International Journal of Innovative Research and Development. 2019; 8(9): 132-138.

[23] Mutayoba SK, Dierenfeld E, Mercedes VA, Frances Y, Knight CD. Determination of chemical composition and antinutritive components for Tanzanian locally available poultry feed ingredients. International Journal of Poultry Science. 2011; 10: 350-357.

[24] Richter N, Perumal S, Becker K. Evaluation of nutritional quality of Moringa(Moringa oleifera Lam.) leaves as an alternative protein source for Nile tilapia (Oreochro misniloticus L.). Journal of Aquaculture. 2003; 217(1): 599611.

[25] Abbas RK, Fatma SE, Abdalfatah AF. Nutritional Values of Moringa oleifera, Total Protein, Amino Acid, Vitamins, Minerals, Carbohydrates, Total Fat and Crude Fiber, under the Semi-Arid Conditions of Sudan. Journal ofMicrobial and Biochemical Technology. 2018; 10(2):56-58.

[26] Kakengi AMV, Kaijage JT, Sarwatt SV, Mutayoba SK, Shem MN, Fujihara T. Effect of Moringa oleifera leaf meal as a substitute for sunflower seed meal on performance of laying hens in Tanzania. Journal of Livestock Research for Rural Development. 2007; 19(8).

[27] Valdez-Solana MA, Mejía-García VY, Téllez-Valencia A, García-Arenas, G, Salas-Pacheco J, Alba-Romero JJ, SierraCampos E. Nutritional Content and Elemental and Phytochemical Analyses of Moringa oleifera Grown in Mexico. Journal of Chemistry. 2015;9. 
[28] Verma AR, Vijayakumar M, Mathela CS, Rao CV. In vitro and invivo antioxidant properties of different fractions of Moringa oleifera leaves," Food and Chemical Toxicology. 2009; 47(9): 2196-2201.

[29] Aengwanich W, Simaraks S, Chinrasri O. Haematological, electrolyte and serum biochemical values of Thai indigenous chickens (Gallus domesticus) in North-eastern Thailand, Songklanakarin. Journal of Science and Technology. 2004; 26(3): 425-430.

[30] Olugbemi TS. Moringa oleifera leaf meal as a hypocholesterolemic agent in laying hen diets. Journalof Livestock Research for Rural Development. 2010; 22(4).

[31] Amevor FK. Moringa (moringa oleifera) leaf meal supplementation on the performance, carcass characteristics and blood profile of broilers. Thesis Submitted to the University of Ghana, Legon in partial fulfillment of the requirement for the award of M.Phil Animal Science Degree. 2017.

[32] Mohan J, KuMar S, Kolluri S, Singh PR, SinghtyagiJ, KatariaJM. Semen Quality Characteristics and Seasonality in Different Varieties of Male Guinea Fowl. Advances in Animal and Veterinary Sciences. 2016; 4(6): 320-326.

[33] Portugaliza HP, Fernandez TJ Jr. Growth performance of Cobb broilers given varying concentrations of malunggay (Moringa oleifera lam). Aqueous leaf extract. Online Journalof Animal Feed Research.2012; 2(6): 465469.

[34] Ashizawa K, Sano R. Effects of temperature on the immobilization and the initiation of motility of spermatozoa in the male reproductive tract of the domestic fowl, Gallus domesticus. Comparative Clinical Pathology. 1990; 96(2): 297-301.

[35] Korankye 0, Kagya-Agyemang JK, Annor SY, Asabere-Ameyaw A, Kyere CG. Effect of Day Length and Seasonal Variation on Haematological, Biochemical and Hormonal Traits of Indigenous Guinea fowl (Numida meleagris) in Ghana. Journal of Animal Research. 2018; 8(2): 1-08.

[36] Tutubalang KA. Effect of dietary Moringa oleifera leaf meal on egg fertility and sperm quality of Potchefstroom koekoek indigenous chicken. A Dissertation accepted in fulfilment of the requirements for the degree of Masters of Science in Agriculture in Animal Science at the North West University. 2019.

[37] Aderinola OA, Rufiu TA, Akinwumi AO, Alabi TA, Adeagbo OA. Utilization of Moringa oleifera leaf as feed supplement in broiler diets. International Journal of Food, Agricultural and Veterinary Sciences. 2013; 3(3): 94102.

[38] Mashaly MM, Hendricks GL, Kalama MA, Gehad AE, Abbas AO, Patterson PH. Effect of heat stress on production parameters and immune responses of commercial laying hens. Journal of Poultry Science. 2004; 83:889-894.

[39] Deng W, Dong XF, Tong JM, Zhang Q. The probiotic Bacillus licheniformis ameliorates heat stress-induced impairment of egg production, gut morphology, and intestinal mucosal immunity in laying hens. Journal of Poultry Science. 2012; 91:575-582.

[40] Birger AM. The complete blood cell count: A powerful diagnostic tool. Journal of Veterinary Clinical. North America Small Animal Practice. 2014; 33: 1207-1222.

[41] Iheukwumere FC, Ndubuisi EC, Mazi EA, Onyekwere MU. Growth, blood chemistry and carcass yield of broilers fed cassava leaf meal (Manihot esculenta Crantz). International Journal of Poultry Science. 2008; 6(8): 555-559.

[42] Elagib HAA, Musharaf NA, Makawi SA, Mohamed HE. Effects of Age and Season on Semen Characteristics of White Leghorn Cocks under Sudan Conditions. International Journal of Poultry Science. 2012; 11(1): 47-49.

[43] Kout K, Moustafa ME, Ghazalah AA, Rehan AAA. Effect of Dietary Nanosilveron broiler performance. International Journal of Poultry Science. 2015; 14(3): 177-182.

[44] Binali W, Kanengoni E. Guinea fowl production. A Training Manual Produced for the use by Farmers and Rrural Development agents. Agritex, Harare, Zimbabwe. 1998; 35.

[45] Makanjuola BA, Obi O0, Olorungbohunmi TO, Morakinyo OA, Oladele BMO. Effect of Moringa oleifera leaf meal as substitute for Antibiotics. 2014.

[46] Cynthia K, Merck S, Dohme C. The Merck Veterinary Manual 10th (tenth) edition. Merck Sharp and Dohme Corporation. 2010.

[47] Nalubamba KS, Mudenda NB, Bwalya EC, Masuku M, Munyeme M, Munang'andu HM.Seasonal variations in health indices of free-ranging asymptomatic Guinea fowls (Numida meleagris) in Zambia. Asian Pakistan Journal ofTropical Medicine. 2014; 7(1): 143-149. 
[48] Yokus B, Caki, DU, Kanay Z, Gulten T, UysalE. Effects of Seasonal and Physiological Variations on the Serum Chemistry, Vitamins and Thyroid Hormone Concentrations in Sheep. Journal of Veterinary Medicine. 2006;53: 271-276.

[49] Jesuyon OMA, Salako AE. Effect of Seasons on the Reproductive Performance of BovanNera and Isa Brown Parentstock Chickens in a Hot Humid Environment. International Journal of Animal and Veterinary Advances. 2012; 5(6): 212-21.

[50] Elaroussi MA. Developing heat and cold tolerance indices in chickens with the use of radioisotopes. M.Sc. Thesis, Faculty of Agriculture. Ain Shams University, Egypt. 1981.

[51] Renema IA, Robinson FE, Proudman JA, Newcombe M, Mckay RI. Effects of Body Weight and Feed Allocation During Sexual Maturation in Broiler Breeder Hens. 2. Ovarian Morphology and Plasma Hormone Profiles. Journal of Poultry Science. 1999; 78:629-639.

[52] Bocchinfuso WP, Hammond GL. Sex hormone-binding globulin/androgen-binding protein: Steroid-binding and dimerization domains. Journal of Steroid Biochemistry and Molecular Biology. 1995; 53(1-6):543-552.

[53] Becker K. Studies on utilization of Moringa oleifera leaves as animal feed. Institute for Animal Production in the Tropics and Subtropics, vol. 480.University of Hohenheim, Stuttgart. 1995; 15.

[54] Bjornerem Å, Straume B, Pal O, Berntsen GKR. Seasonal Variation of Estradiol, Follicle Stimulating Hormone, and Dehydroepiandrosterone Sulfate in Women and Men. The Journal of Clinical Endocrinology and Metabolism. 2006; 91(10): 3798-3802.

[55] Balog JM, Bayyari GR, Rath NC, Huff WE, Anthony NB. Effect of intermittent activity on broiler production parameters. Journal of Poultry Science. 1997; 76: 6-12.

[56] Dunn IC, Sharp PJ. Photo Induction of Hypothalamic Gonadotrophin Releasing Hormone-I mRNA in the Domestic Chicken: a Role for Oestrogen?: PhotoInduction of Hypothalamic Gonadotrophin Releasing Hormone-I mRNA in the Domestic Chicken: a Role for Oestrogen? Journal of Neuroendocrinology. 2001; 11(5):371-375.

[57] Milica ŽB, Sandra J, Slobodan K, Miloš K. Electrolytes - sodium, potassium and chlorides in poultry nutrition. Archive veterinarske medicine. 2016; 9(1): 31 - 42.

[58] Murakami AE. Estimation of the sodium and chloride requirements for the young broiler chick. Journal of Applied Poultry Research. 1997; 6: 155-162. 